\title{
Piezoelectric Immunosensor for the Determination of Immunoglobulin G
}

\author{
Miroslav Pohanka \\ Faculty of Military Health Sciences, University of Defence, Trebesska 1575, CZ-500 01 Hradec \\ Kralove, Czech Republic \\ E-mail: miroslav.pohanka@gmail.com
}

doi: $10.20964 / 2018.09 .01$

Received: 28 August 2017 / Accepted: 8 November 2017 / Published: 5 August 2018

Immunoglobulin $\mathrm{G}$ ( $\mathrm{IgG}$ ) is an immunochemical marker with broad importance because of its employment in various diagnoses like chronic infections, some inflammatory diseases, hyperimmunization, multiple myeloma, leukemia or lymphoma. The IgG level in blood or blood plasma is typically measured by an instrumental method from which Enzyme-Linked Immuno-Sorbent Assay (ELISA) is the most important one. Simple method suitable for field or homecare is however missing. This paper is devoted to the construction of immunochemical biosensor based on Quartz Crystal Microbalance (QCM) platform for a simple determination of IgG. A polyclonal antibody specific to IgG was covalently attached to electrode and standard IgG was assayed and the resulted data were validated to ELISA method. The immunosenor was found to be a reliable platform and $\operatorname{IgG}$ was determined with limit of detection $9.7 \mu \mathrm{g} / \mathrm{ml}$ and the achieved calibration fully correlated with ELISA which is perceptible from coefficient of determination $\mathrm{r}^{2}=0.976$. The immunosensor exerted long term stability and it was usable after at least two months. In a conclusion, the immunosensor appears to be a reliable tool for a fast, label-free determination of IgG without any necessity to have expensive equipment or skills.

Keywords: affinity; antibody; biosensor; biorecognition; immunochemistry; immunoglobulin; label free assay; piezoelectric; quartz crystal microbalance

\section{$\underline{\text { FULL TEXT }}$}

(C) 2018 The Authors. Published by ESG (www.electrochemsci.org). This article is an open access article distributed under the terms and conditions of the Creative Commons Attribution license (http://creativecommons.org/licenses/by/4.0/). 